\title{
Clinical Investigator Award (CIA)
}

National Cancer Institute

\section{Source}

National Cancer Institute. Clinical Investigator Award (CIA). NCI Thesaurus. Code C20010.

Provides support and time for an intensive, supervised research career development experience to individuals with a clinical doctoral degree who are committed to a career in laboratory or clinically-based research. 